\title{
Description of the Mate Industrial Agglomerate of the Alto Vale Taquari, Rio Grande do Sul, Brazil
}

\author{
Henrique Piton Greff ${ }^{1}$ (i) 0000-0002-0051-4824 \\ Jorge Antonio de Farias ${ }^{1}$ (D) 0000-0001-7494-4176 \\ Pabulo Diogo de Souza ${ }^{1}$ (D) 0000-0002-2446-8041
}

\begin{abstract}
The mate (Ilex paraguariensis) market of Rio Grande do Sul has experienced the structuring of a productive chain of mate, from the implantation of the herbs, through industrialization, until they reach the final consumer. Thus, more advanced methods of productive and organizational development are necessary, such as the institutionalization of Local Productive Systems. Our study sought to identify and characterize the industrial settlement of the Alto Vale Taquari. The mechanisms adopted to identify the Local Productive Arrangements (LPA) were based on the evaluation of the data of the Annual Social Information Report, on-site verification of the existence of industries and indicators of industrial agglomeration. We identified 33 mate industries, in 5 municipalities. The industrial agglomerate was characterized as a Local Development Vector. Therefore, we observed a need to implement actions that promote the structuring of the agglomerate, especially regarding the institutionalization of governance.
\end{abstract}

Keywords: local productive system, clusters, mate.

\section{INTRODUCTION AND OBJECTIVES}

The understanding of processes that lead to regional development has been linked to socioeconomic factors related to local and agglomerative issues of certain activities that generate employment and income. Among these factors, we emphasize the Local Productive Arrangements (LPA), which is defined as territorial agglomerations with a relationship between intersectoral agents organized to perform a certain set of economic activities (Cassiolato \& Lastres, 2003a; Saraceni \& Andrade, 2013).

Changes resulting from the process of globalization of the economy and the creation of economic blocs, particularly MERCOSUR, resulted in a new reality for the mate productive chain. Historically, this chain carries the paradigm of "traditionalism", both in the habit of chimarrão and in the process of industrial production that, conceptually, has changed little since the beginning of its production. Mate market has experienced a more competitive environment ever since, demanding more advanced methods of development, from the implantation of mate fields, through industrialization, to commercialization, when mate reaches the final consumer.
In the State of Rio Grande do Sul, some regions stood out for the production of mate and the emergence of industries of the mate sector, which began to experience a more competitive environment in the market and has its productive chain organized in six poles, including the Alto Vale Taquari. This denomination originated from the creation and implementation of the RS Forest Program (Rio Grande do Sul, 2010) and the formalization of the "Revitalization Project of the Rio Grande do Sul mate poles".

According to the Sindicato da Indústria o Mate no Estado do Rio Grande do Sul (SINDIMATE, c2011), the largest amount of mate consumed in the state comes from this region, as well as the largest concentration of industries of the sector. These observations strongly indicate the existence of a Local Productive Arrangement in the Alto Vale Taquari region. However, SINDIMATE is still not aware of the identification and characterization of this mate industrial agglomerate.

Due to the wide range of questions regarding the topic Local Productive Arrangements, ranging from its concept to the actions developed in this organizational structure, our study addressed these questions, focusing on issues considered more practical and feasible for the agents.

\footnotetext{
${ }^{1}$ Universidade Federal de Santa Maria (UFSM), Santa Maria, RS, Brasil
} 
The estimate of industrial agglomeration indicators and the application of investigative methodologies that enable the characterization of the actors involved in a given cluster have been technical forms of identification and characterization of local productive arrangements (Leite Filho \& Antoniali, 2011).

Our study sought to identify and characterize the LPA in the Alto Vale Taquari region, by identifying deficiencies that hinder its evolution and, consequently, direct efforts to strengthen the implementation of specific actions of development.

\section{MATERIALS AND METHODS}

The study covered the delimitation of Polo 4 mate sector established by the State, located in the region of the Taquari-Antas Basin, in the northeast of the state of Rio Grande do Sul, and composed of the municipalities of Anta Gorda, Arvorezinha, Coqueiro Baixo, Doutor Ricardo, Fontoura Xavier, Ilópolis, Itapuca, Nova Alvorada, Putinga, Relvado and São José do Herval.

The methodology was based on the simultaneous application of descriptive and exploratory techniques, since it involved a case study, to diagnose the identification and characterization of the mate industrial agglomerate (cluster) located in the Alto Vale Taquari region.

\subsection{Identification of the mate industrial agglomerate}

The comprehensiveness and classification of the mate industrial agglomerate was conducted as follows:

1. Annual Social Information Ratio (RAIS) data analysis - the criterion of exclusion of a municipality was established according to the lack of job positions in the sectors "Manufacture of food products not specified previously" (CNAE 10694) and "Grinding and manufacturing of products of plant origin not specified previously" (CNAE 10996), these being the sectors related to the industrial activities of mate, according to the National Classification of Economic Activities (CNAE 2.0).

2. On-site verification of the existence of industries - as the RAIS data refer to the year prior to the survey (2014), the existence of companies linked to the sector was confirmed based on consultations with public institutions such as the Instituto Brasileiro da Erva-Mate (IBRAMATE) and the SINDIMATE. Thus, the municipality in which there was no registration of active companies was excluded from the cluster.
3. Assessment of industrial agglomeration indicators - to verify the identification, importance and classification of the arrangement, the following indicators were applied: Locational Quotient (Equation 1); participation of employment of the economy class in the region compared to the total employment in the state (Equation 2); and minimum number of establishments, according to the methodology described by Leite Filho and Antoniali (2011).

$$
\begin{array}{r}
L Q=\frac{\frac{E_{i j}}{E_{i}}}{\frac{E_{R S i j}}{E_{R S i}}} \\
P(\%)=\frac{E_{i j}}{E_{R S i}}
\end{array}
$$

$E_{i j}$ :Emplo33yment of industrial activity i in region $j ; E_{i}$ : Total industrial employment in region $j ; E_{R S i i}$ : Employment of industrial activity $i$ in Rio Grande do Sul; $\mathrm{E}_{\mathrm{RSi}}$ : Total industrial employment in Rio Grande do Sul.

\subsection{Characterization of the mate industrial agglomerate}

The methodology used to characterize the industrial agglomeration was based on the questionnaires of the Research Network on Local Productive and Innovative Systems (Cassiolato \& Lastres, 2003b) of the Universidade Federal do Rio de Janeiro (UFRJ), in which the data was collected with the application of questionnaires directed to companies, to address the following items:

1. Company identification: size of the company, origin and structure of capital, number of employees;

2. Production, market and job positions: qualification of the workforce, destiny of the sales, evolution of the billing and competitive capacity;

3. Innovation, cooperation and learning: innovative efforts, costs involved, results attributed to such an effort, activity learning and cooperation with various agents;

4. Governance structure and advantages associated to the local environment: productive structure, governance and specific advantages;

5. Public policies and forms of financing: participation in specific action programs for the segment, promoted by the federal, state or municipal government or by other institutions. 


\subsection{Sampling}

The methodology used by Barbetta (2006), according to Equations 3 and 4, was applied to perform the sampling of the mate companies in the Alto Vale Taquari region.

$$
\begin{aligned}
& P(\%)=\frac{1}{E_{0}^{2}}=\frac{1}{0,10^{2}}=100 \\
& n=\frac{N^{*} n_{0}}{N+n_{0}}=\frac{33 * 100}{33+100} \cong 25
\end{aligned}
$$

$n_{0}$ : sample intensity to reach the maximum permissible error as $E_{0} ; N$ : population size; $n$ : corrected sample intensity.

Therefore, 25 mate companies were randomly selected and interviewed, thus representing the population of this activity in the region. The interviews were conducted on-site with the owners of the industries.

\section{RESULTS AND DISCUSSION}

\subsection{Identification of the mate industrial agglomerate}

The mate industrial agglomeration of the Alto Vale Taquari region was delimited in five municipalities (Arvorezinha, Doutor Ricardo, Fontura Xavier, Ilópolis and Putinga). Based on RAIS data, four of the eleven municipalities initially delimited (Coqueiro Baixo, Nova Alvorada, Relvado and São José do Erval) did not have employees in the mate sector. Moreover, two other municipalities (Anta Gorda and Itapuca) did not have records of employees linked to the industrial activity of mate according to local institutions, that is, there were no establishments linked to the industrial activity in 2015 (Table 1).

The emphasis on municipalities with active enterprises is justified by the fact that these industries represent real possibilities of strengthening market competitiveness, based on actions such as the enhancement of synergy policies among them, expanding issues such as learning, information exchange, equipment purchases and inputs into groups, etc. Moreover, the methodology used by Redesist consists of the characterization of the arrangement through interviews with the industries, which justified the exclusion of municipalities with no current industrial activities of the mate industry. Thus, it is noteworthy that these municipalities play important roles in the production chain of mate, mainly related to the supply of raw material.

It is also noteworthy that the labor reality of the mate sector is based on informal employment bonds, in addition to temporary hiring at the time of harvest. Therefore, the generation of job opportunities in the mate sector is probably greater than the official data presented.

Table 1. Number of employees linked to the industrial activity of

\begin{tabular}{|c|c|c|c|}
\hline \multirow{2}{*}{ Municipality } & \multicolumn{2}{|c|}{ CNAE code } & \multirow[b]{2}{*}{$\%$} \\
\hline & $10694^{1}$ & $10996^{2}$ & \\
\hline Anta Gorda & - & 2 & 0.59 \\
\hline Arvorezinha & 2 & 168 & 49.85 \\
\hline Coqueiro Baixo & - & - & - \\
\hline Doutor Ricardo & 11 & - & 3.23 \\
\hline Fontura Xavier & - & 11 & 3.23 \\
\hline Ilópolis & 57 & 71 & 37.54 \\
\hline Itapuca & - & 1 & 0.29 \\
\hline Nova Alvorada & - & - & - \\
\hline Putinga & - & 18 & 5.28 \\
\hline Relvado & & & - \\
\hline São José do Herval & - & - & - \\
\hline Rio Grande do Sul & 1,601 & 7,020 & \\
\hline
\end{tabular}
production of mate at pole 4 of the mate sector of Rio Grande do Sul.

Regarding the evaluation of indicators of industrial agglomeration, since the processing of the mate leaf product does not have a unique classification, we decided to conduct the determination of the values of $L Q, P$ and $E$, considering the sum of the number of employees for the CNAE 10964 and 10996, since both codes are allusive to the mate companies. Thus, the values of the signs $L Q, P$ and $E$ were, respectively, $17.8,4 \%$ and 33 ; indicating that it is a region specialized in activities of the industrial sector of mate, mainly evidenced by the fact that the value of $L Q$ was higher than 1 . These results emphasize the representativeness of the mate industry in the Alto Vale Taquari region.

\subsection{Characterization of the mate industrial agglomerate}

The characterization of a cluster results from the need for establishing the richness and the demands of the region considering the LPA concepts, as well as to diagnose the profile of the existing agents, to consolidate activities that strengthen their qualities (Silveira \& Moraes, 2010).

Thirty-three companies of the segment were diagnosed and distributed in five municipalities (Arvorezinha, Doutor Ricardo, Fontura Xavier, Ilópolis and Putinga), all of which were allocated an average distance of only $20 \mathrm{~km}$. According to the company classification criteria described by the Serviço Brasileiro de Apoio às Micro e Pequenas Empresas (Sebrae), we found that these industries are made up of micro and small enterprises and employ about 400 direct employees (Table 2). 
Table 2. Size of the companies of Polo 4 of the mate sector.

\begin{tabular}{lcccc} 
Company size & No companies $^{\circ}$ & $\%$ & No employees $^{\circ}$ & $\%$ \\
\hline Micro & 18 & 72 & 158 & 39.7 \\
\hline Small & 7 & 28 & 240 & 60.3 \\
Medium & 0 & 0 & 0 & 0 \\
Big & 0 & 0 & 0 & 0 \\
Total & 25 & 100 & 398 & 100 \\
\hline
\end{tabular}

These results reinforce the diagnosis of the existence of a local productive agglomerate in the region. Saraceni \& Andrade (2013) corroborate the findings when emphasize the agglomeration of small companies as a characteristic of local productive agglomerates. They also affirm that the existence of joint actions especially aimed at improving the competitive characteristics of the LPA is desirable in productive agglomerates.

In Rio Grande do Sul, the growth and participation of small and medium enterprises (SMEs) are very important in the economy, according to surveys of the Labor Yearbook (Sebrae, 2015). In 2013, Rio Grande do Sul was the state of the South region of Brazil with the largest number of SMEs, reaching 598,233 of Micro and Small companies. According to the same institution, at the national level, Rio Grande do Sul occupies the third place when considered the number of SMEs, only behind Minas Gerais (737,767 companies) and São Paulo (2,036,868 companies).

Regarding the profile of the companies in the sector, most companies (92\%) are classified as independent, whereas the others (8\%) are classified as affiliated or as a subsidiary of a company. Regarding the profile of the founders, almost all of the mate companies were constituted of national capital, with $85.1 \%$ and $90.3 \%$ of the companies, for the respective years of 2013 and 2014. Moreover, it was evident that those companies did not use to borrow from financial institutions, since only $13.4 \%$ and $9.7 \%$ of them used such funds in those years.

The analysis also evidenced that most of the entrepreneurs (76\%) were farmers who cultivated mate and distributed to other brands before exercising the activity. This demonstrates that the LPA resulted from the articulation of actors that were already inserted in the base of the production chain of mate and confirms the notoriety of the socioeconomic progress in the region provided by the mate industry.

Still regarding the profile of the entrepreneurs, the age group is concentrated between 30 and 50 years, with education level restricted to basic education (secondary and fundamental education) (Table 3). However, the mate entrepreneurs affirmed that the low schooling was not an obstacle to their insertion in the business market. On the other hand, Santini et al. (2015) state that schooling reflects in distinct social and cultural environments, with different levels of access to opportunities.

It is clear that this factor will influence the ability to learn more easily, increasing the chances of understanding changes and gaining comparative advantage over competitors. However, similar to the results found by Petter et al. (2010), who analyzed the maturity of the Bonés de Apucarana LPA, it was diagnosed that the mate producers consider the level of schooling as an indispensable factor for conducting managerial activities.

Table 3. Characteristics of the industrial agglomerate entrepreneurs of the Alto Vale Taquari region.

Specification $\quad$ Founder

\section{Age}

$\begin{array}{lc}\text { 1.1. Up to } 20 \text { years } & 0.0 \% \\ \text { 1.2. Between } 21 \text { and } 30 \text { years } & 12.0 \% \\ \text { 1.3. Between } 31 \text { and } 40 \text { years } & 48.0 \% \\ \text { 1.4. Between } 41 \text { and } 50 \text { years } & 40.0 \% \\ \text { 1.5. Above } 50 \text { years } & 0.0 \% \\ \text { Total } & 100.0 \%\end{array}$

2. Gender (\%)

$\begin{array}{lc}\text { 2.1. Men } & 96.0 \% \\ \text { 2.2. Women } & 4.0 \% \\ \text { Total } & 100.0 \% \\ \text { 3. Parent company (\%) } & \\ \text { 3.1. Yes } & 28.0 \% \\ \text { 3.2. No } & 72.0 \% \\ \text { Total } & 100.0 \% \\ \text { 4. Schooling (\%) }\end{array}$

4. Schooling (\%)

\begin{tabular}{lc} 
4.1. Illiterate & $0.0 \%$ \\
4.2. Middle school incomplete & $32.0 \%$ \\
4.3. Middle school complete & $20.0 \%$ \\
4.4. Incomplete high school & $4.0 \%$ \\
\hline 4.5. Complete high school & $32.0 \%$ \\
4.6. Incomplete higher education & $4.0 \%$ \\
\hline 4.7. Complete higher education & $8.0 \%$ \\
4.8. Postgraduate studies & $0.0 \%$ \\
Total & $100.0 \%$ \\
\hline 5. Activity before creating the company (\%) & \\
\hline 5.1. University student & $0.0 \%$ \\
5.2. Technical school student & $0.0 \%$ \\
\hline 5.3. Employee of a micro or small local company & $0.0 \%$ \\
\hline 5.4. Employee of medium or large local company & $0.0 \%$ \\
\hline 5.5. Employee of a company out of arrangement & $0.0 \%$ \\
\hline 5.6. Employee of a public institution & $8.0 \%$ \\
\hline 5.7. Entrepreneurs & $16.0 \%$ \\
\hline 5.8. Other (Farmer) & $76.0 \%$ \\
\hline Total & $100.0 \%$ \\
\hline
\end{tabular}

Considering industrial growth, since $60 \%$ of respondents' enterprises were implemented between 2000 and 2015, Alto Vale Taquari is characterized as a region of economic growth, 
with a mobilization of agents and competitiveness stimulated by new enterprises (Santini et al., 2015). Antoni (1999), when studying the competitive structure of the mate industry of Rio Grande do Sul, showed a high degree of fragmentation of the industry and a delineation of the scenario marked by the inexistence of organizations, with dominant participation in the market and few entry barriers.
When comparing the operational difficulties of the companies in the year of study with those in the initial year of operation, we diagnosed an improvement in the items "Capital for acquisition of machines" and "Capital for rental of facilities," which demonstrates the consolidation of the market in the study region. This shows the bargaining power in this scenario, linked to the survival capacity of the companies (Table 4).

Table 4. Difficulties for business operation.

\begin{tabular}{|c|c|c|c|c|c|}
\hline \multirow{2}{*}{ Difficulty } & \multirow{2}{*}{ Base year } & \multicolumn{4}{|c|}{ Difficulty level } \\
\hline & & High & Medium & Low & Null \\
\hline \multirow{2}{*}{ Hire employees } & Initial year & $17 \%$ & $31 \%$ & $39 \%$ & $13 \%$ \\
\hline & 2014 & $32 \%$ & $28 \%$ & $8 \%$ & $32 \%$ \\
\hline \multirow{2}{*}{ Sell production } & Initial year & $32 \%$ & $30 \%$ & $13 \%$ & $22 \%$ \\
\hline & 2014 & $24 \%$ & $36 \%$ & $16 \%$ & $24 \%$ \\
\hline \multirow{2}{*}{$\begin{array}{l}\text { Capital for acquisition of } \\
\text { machines }\end{array}$} & Initial year & $26 \%$ & $13 \%$ & $22 \%$ & $39 \%$ \\
\hline & 2014 & $0 \%$ & $0 \%$ & $28 \%$ & $72 \%$ \\
\hline \multirow{2}{*}{ Interest payment } & Initial year & $22 \%$ & $9 \%$ & $8 \%$ & $61 \%$ \\
\hline & 2014 & $0 \%$ & $12 \%$ & $12 \%$ & $76 \%$ \\
\hline \multirow{2}{*}{ Produce with quality } & Initial year & $17 \%$ & $22 \%$ & $26 \%$ & $35 \%$ \\
\hline & 2014 & $4 \%$ & $20 \%$ & $28 \%$ & $48 \%$ \\
\hline \multirow{2}{*}{$\begin{array}{l}\text { Cost or lack of working } \\
\text { capital }\end{array}$} & Initial year & $26 \%$ & $22 \%$ & $9 \%$ & $43 \%$ \\
\hline & 2014 & $8 \%$ & $16 \%$ & $24 \%$ & $52 \%$ \\
\hline \multirow{2}{*}{ Capital for rental of facilities } & Initial year & $13 \%$ & $9 \%$ & $17 \%$ & $61 \%$ \\
\hline & 2014 & $0 \%$ & $0 \%$ & $8 \%$ & $92 \%$ \\
\hline
\end{tabular}

Regarding the capacity to hire employees, there was a tie between the high and low difficulty level when compared with the base year (2014). This is possibly related to the fact that, although the Alto Vale Taquari mate industrial grid is composed of SMEs, a great disparity between the brands is evident and, consequently, the capacity of payment, in which companies that produce with better quality stand out.

According to Silva \& Cassol (2003), the production of mate is present in about 180 thousand properties in the country, most considered as small agricultural establishments (from 1 to 15 hectares), totaling about 600 companies and more than 700,000 job positions.

The mate sector is very important for the region under study. In 2011, 775 out of 780 rural properties of the region worked with mate production. It is also noteworthy that 2,500 out of 4,088 rural inhabitants are involved with the mate industry. From 2000 to 2014, the number of employees in the companies interviewed increased on average $46.57 \%$. The agrobusiness industry, especially microenterprises, make great use of family labor, in contrast with the reality of Brazilian agroindustry.
Regarding the market, the region's mate production has been destined almost entirely for consumption in the state of Rio Grande do Sul, with an average of $91.70 \%$, and only $4.03 \%$ considered as remainder destined for export. This market still follows the trends observed by Antoni (1999) in the 1990s, which observed that only $5 \%$ of production is destined for consumption in other regions of Brazil or export. Furthermore, according to FUNDOMATE (2017), Rio Grande do Sul is the most representative state in the export of the product. In December $2016,81 \%$ of the exported mate came from the state. The mate producers report that the greatest difficulties regarding possible export opportunities are the bureaucratic barriers and the costs themselves.

By analyzing the degree of importance of competitive factors in the main product line of the interviewees, we observed that the three main factors that determine the competitive capacity of the company are "product quality," "quality of raw material and other inputs" and "attendance capacity (volume and term)". While the factor "introduction of new products/processes" was the lesser element for competitiveness (Table 5). These results show that the industrial production of mate is quite solid, because it has a consolidated process and low technological level. 
Table 5. Diagnosis of the degree of importance of competitive factors in the Alto Vale Taquari industry.

\begin{tabular}{|c|c|c|c|c|}
\hline \multirow{2}{*}{ Competitive factors } & \multicolumn{4}{|c|}{ Degree of importance } \\
\hline & Null & Low & Medium & High \\
\hline 1. Quality of raw materials and other inputs & $0.0 \%$ & $0.0 \%$ & $12.0 \%$ & $88.0 \%$ \\
\hline 2. Quality of labor & $0.0 \%$ & $0.0 \%$ & $32.0 \%$ & $68.0 \%$ \\
\hline 3. Labor cost & $4.0 \%$ & $16.0 \%$ & $44.0 \%$ & $36.0 \%$ \\
\hline 4. Technological level of equipment & $0.0 \%$ & $4.0 \%$ & $36.0 \%$ & $60.0 \%$ \\
\hline 5. Ability to introduce new products/processes & $28.0 \%$ & $20.0 \%$ & $28.0 \%$ & $24.0 \%$ \\
\hline 6. Design and style in products (packaging) & $0.0 \%$ & $4.0 \%$ & $36.0 \%$ & $60.0 \%$ \\
\hline 7. Marketing strategies & $8.0 \%$ & $0.0 \%$ & $16.0 \%$ & $76.0 \%$ \\
\hline 8. Product quality & $0.0 \%$ & $0.0 \%$ & $0.0 \%$ & $100.0 \%$ \\
\hline 9. Capacity of service (volume and term) & $0.0 \%$ & $4.0 \%$ & $12.0 \%$ & $84.0 \%$ \\
\hline
\end{tabular}

The innovations employed in the LPA industries were mainly related to the packaging of the final product. There was little innovation regarding the technological aspects involved in the processes, which is also explained by the solidity of the beneficiation process of the mate (Table 6). Significant organizational innovations were also diagnosed, since companies began to seek qualified professionals to improve the areas of administration, marketing and plant nutrition to increase competitiveness in the mate market.

These results are consistent with Saraceni \& Andrade (2013) analogy, which point out that what inhibits research and technology investments to achieve technological innovations in agglomerates is the risk that these innovative actions may not be profitable.

The competitive advantages were analyzed in the context of the LPA's location, being the proximity with suppliers of raw material verified as the great advantage of the region, reaching $87.5 \%$ of the opinions, which was already expected, since this is the region of the greatest production of mate of the state. Infrastructure was another significant advantage, involving energy, transportation and communications offered by municipalities, with most managers' votes (54.2\%) (Figure 1).
1: proximity to suppliers of inputs and raw materials; 2 : proximity to customers/consumers; 3 : availability of physical infrastructure (energy, transportation, communications); 4: proximity to producers of equipment; 5 : availability of technical services; 6: proximity to universities and research centers.

Based on the analysis of the main indicators of regional development related to the market and workforce, we could estimate indexes to evaluate topics relevant to commercial transactions, characteristics of the local workforce, and the contribution of regional institutions to collective actions in the region (Table 7).

Regarding the characteristic of the type of commercial transaction, the most important factor is the transaction of inputs and raw material, as well as maintenance and marketing services. The limitation was notable, since the region under study did not produce machines for the processing of mate plants, as shown in Figure 1.

Regarding the characteristics of the workforce, as expected, the degree of schooling was not understood by the mate producers as a significant factor for the characteristics of the workforce due to the relatively low level of technology employed in the process of industrialization of mate plants. Moreover, the entrepreneurs prefer characteristics such as "practical knowledge" and "discipline in the work".

Table 6. Innovations employed in the companies that are part of the industrial agglomerate of the Alto Vale Taquari.

\begin{tabular}{lcc} 
& \multicolumn{2}{c}{ PMEs } \\
\cline { 2 - 3 } Description & Yes & No \\
\hline 1. Product innovations & $40 \%$ & $60 \%$ \\
2. Process innovations (technological aspects) & $36 \%$ & $64 \%$ \\
3. Innovations in the final product (packaging) & $68 \%$ & $32 \%$ \\
4. Organizational innovations & $68 \%$ & $32 \%$ \\
\hline
\end{tabular}




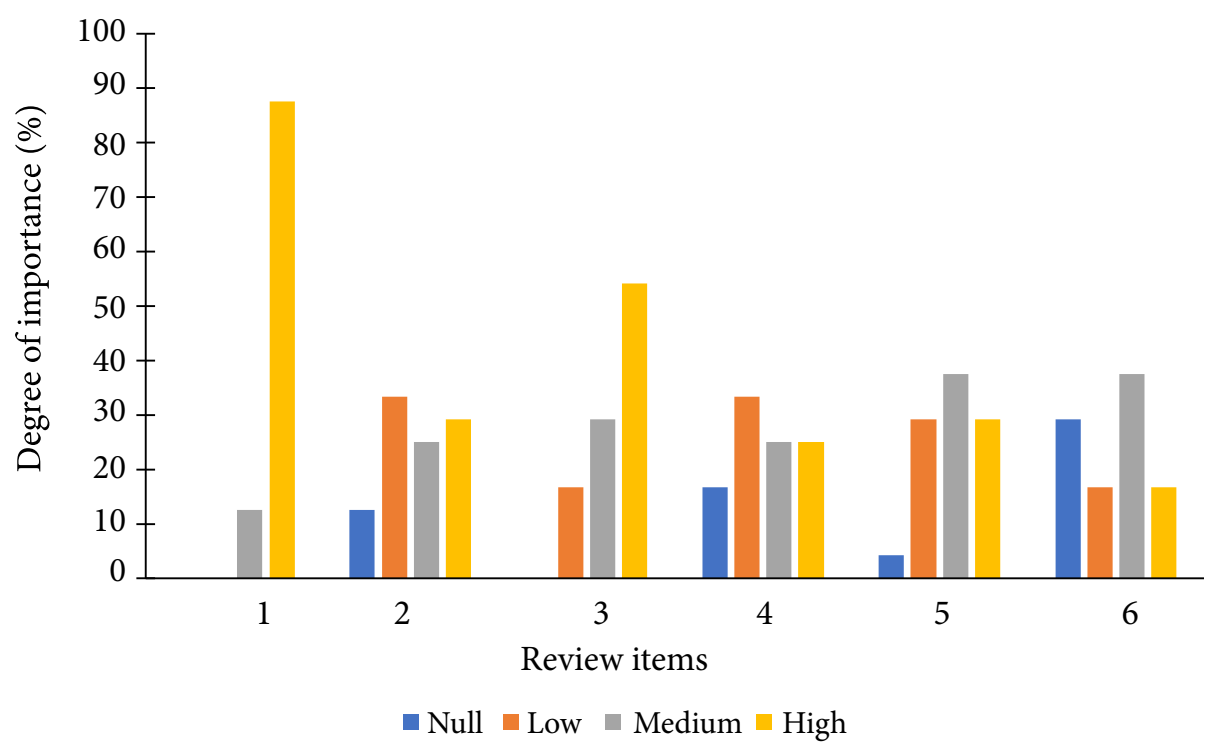

Figure 1. Degree of importance of the competitive advantages in the industrial agglomerate of the Alto Vale Taquari.

Table 7. Valuation indices pertaining to types of commercial transactions, labor characteristics and type of contribution of regional institutions.

\begin{tabular}{|c|c|}
\hline Types of business transactions & Index ${ }^{*}$ \\
\hline Acquisition of raw materials and inputs & 0.92 \\
\hline Acquisition of equipment & 0.53 \\
\hline Acquisition of components and parts & 0.55 \\
\hline Acquisition of services (maintenance, marketing, etc.) & 0.66 \\
\hline Product sales & 0.54 \\
\hline Labor characteristics & Index ${ }^{\star}$ \\
\hline Schooling: middle and high school & 0.68 \\
\hline Education: higher education and technical & 0.56 \\
\hline Practical knowledge in production & 0.95 \\
\hline Discipline & 0.95 \\
\hline Flexibility & 0.87 \\
\hline Creativity & 0.83 \\
\hline Ability to learn new skills & 0.81 \\
\hline Type of contribution of the institutions & Index ${ }^{*}$ \\
\hline Stimulus in the perception of future visions for strategic action & 0.59 \\
\hline Organization of technical and commercial events & 0.57 \\
\hline Providing information on raw materials and equipment, technical assistance, consulting, etc. & 0.54 \\
\hline Encouraging in the development of the local teaching and research system & 0.53 \\
\hline Assistance in the definition of common objectives for the productive arrangement & 0.51 \\
\hline Creation of forums and environments for discussion & 0.50 \\
\hline Promotion of actions aimed at the technological qualification of companies & 0.45 \\
\hline Presentation of common claims & 0.43 \\
\hline Promotion of cooperative actions & 0.32 \\
\hline Identification of sources and forms of financing & 0.15 \\
\hline
\end{tabular}

${ }^{*}$ Index: $\left(0^{*} n^{\circ}\right.$ nulls $+0,3^{*} n^{\circ}$ medium $+n^{\circ}$ high $)$. 
Despite the two institutions with great potential to play such a role in this LPA, no consolidated governance was diagnosed. The first, SINDIMATE, seeks to promote an interaction between its members and the entire production chain of mate; and the second, IBRAMATE, aims to promote an interaction between the legal entities (representing the producers) and the mate processing industries. Thus, the need for an effective institution of governance in this agglomerate is evidenced, since the roles of these actors are essential in the articulation of commercial, institutional and industrial relations according to the specific needs of the cluster (Petter et al., 2010).

However, the mate producers do not see the importance of the action of these institutional agents, since the indices found were between medium and low (Table 7). These results show that the LPA is characterized by a low level of cooperative dynamism.

Regarding the public policies in the scope of financing of the activities of the LPA, the herbalists do not see the influence of such actions in their activities, evidenced by their ignorance regarding the financing tools.

\subsection{LPA typology}

According to the classification proposed by Suzgan et al. (2009), the LPA Alto Vale Taquari is classified as a "Local Development Vector", that is, it shows great importance at the regional level, but it is still of little significance for the state. Despite the absence of LPA in the state of Rio Grande do Sul classified by such methodology, the great potential of the LPA of the Alto Taquari Valley to be recognized by the Agência Gaúcha de Desenvolvimento e Promoção do Investimento (AGDI) can be observed.

Regarding the comprehensiveness, when comparing it with another cluster already recognized in the state, the Agroindustry's LPA, which has a ratio of 1:3,6 between the number of municipalities and industries that compose it (13 municipalities and 47 industries), it is observed that the agglomerate of mate producers presents a ratio of 1:6,6 (5 municipalities and 33 industries).

Based on the analogy proposed by Mytelka \& Farinelli (2000), the mate production LPA is classified as "informal LPA". Although it is composed of small companies that are relevant to the regional market, it has an informal nature due to some peculiarities, such as: limited managerial capacity, little employment of skilled labor and cooperative ability, incipient innovative capacity, as well as unconsolidated governance. This diagnosis evidences the need to develop actions essential to the consolidation of solid governance in this LPA.
Governance makes more effective the actions aiming at the resolution or minimization of local problems resulting from agglomeration or territorial specialization. According to Petter et al. (2010), such actions enable to strengthen factors inherent in the competitive characteristics of the LPA, such as the optimization of costs and the increase of productive and innovation capacity.

With the institutionalization of governance, it would be possible to begin consolidating horizontal network ties, that is, strengthening reciprocal interdependence among mate producers to stimulate the development of the sectoral complementarity of the export base. Thus, mate producers could form alliances to share physical resources and exchange knowledge and even jointly develop innovative actions (Masquietto et al., 2011).

\section{CONCLUSIONS}

Considering the analysis of proposals applied in the LPA, we could diagnose the mate production LPA of the Alto Vale Taquari and characterize it based on consecrated typologies.

Thus, by considering the aforementioned characteristics/ deficiencies, it is possible to draw up plans and actions that can contribute to the evolution of the development of the arrangement, such as:

- Encouraging strategic alliances (cooperation), which is important to enable companies to respond to the challenges posed by globalization and get into new markets;

- Partnerships with industries in other sectors, such as food, pharmacological, etc., which would be a way to obtain products with higher added value;

- An environment with "neighborhood ties, facilitates the dissemination of knowledge" (Marshall, 1982). An interactive link between companies increases the flow of ideas, making the region more receptive to innovation;

- The lack of governm ent policy for the product or the lack of knowledge of those government policies by the managers results in low prioritization of concrete mechanisms of development and modernization.

Our study showed that the LPA need actions aiming at the development of the sectorial complementarity of its export base due to the absence of a consolidated governance. Thus, a possible alternative may be the creation of an institutionalized governance, in which public institutions can represent all the actors of the LPA in a cohesive and organized way in partnership with the private entities that act in the region. 


\section{ACKNOWLEDGEMENTS}

The authors thank the Programa de Pós-Graduação em Engenharia Florestal (PPGEF) of Universidade Federal de Santa Maria (UFSM).

\section{SUBMISSION STATUS}

Received: 22 Mar. 2018

Accepted: 18 Feb. 2019

Associate editor: Vanessa Maria Basso

(D) 0000-0003-3141-2262

\section{CORRESPONDENCE TO \\ Pabulo Diogo de Souza}

Universidade Federal de Santa Maria (UFSM), Av. Roraima, 1.000, Camobi, CEP 97105-900, Santa Maria, RS, Brasil e-mail: pabulodiogo@gmail.com

\section{REFERENCES}

Antoni VL. A estrutura competitiva da indústria ervateira do Rio Grande do Sul. Revista Teoria e Evidência Econômica 1999; 7(12): 49-68. 10.5335/rtee.v7i12.4798

Barbetta PA. Estatística aplicada às ciências sociais. 6th ed. Florianópolis: UFSC; 2006. p. 55-63.

Cassiolato JE, Lastres HMM. Glossário de arranjos de sistemas produtivos e inovativos locais. In: Lastres HMM, Cassiolato JE. Arranjos produtivos locais: uma nova estratégia de ação para o Sebrae. Rio de Janeiro: Redesist; 2003a. p. 8-24.

Cassiolato JE, Lastres HMM. O foco em arranjos produtivos e inovativos locais de micro e pequenas empresas. Rio de Janeiro: Redesist; 2003b.

Fundo de Desenvolvimento e Inovação da Cadeia Produtiva da Erva-Mate - FUNDOMATE. Informativo do Fundomate [Internet] 2017 [cited 2017 Jul. 15]; (27). Available from: https://bit.ly/3ddzJJs

Leite Filho GA, Antoniali LM. Proposta de classificação de arranjos produtivos locais por indicadores de identificação: um estudo multivariado. Interações 2011; 12(1): 53-64. 10.1590/S151870122011000100006
Marshall A. Princípios de economia: tratado introdutório. São Paulo: Abril Cultural; 1982.

Masquietto CD, Sacomano Neto M, Giuliani AC. Centralidade e densidade em redes de empresas: um estudo no arranjo produtivo local do álcool. Revista de Administração e Inovação 2011; 8(1): 122-147. 10.5773/rai.v8i1.456

Ministério do Trabalho e Emprego - MTE. Relação Anual de Informações Sociais [Internet]. 2014 [cited 2014 Dec. 10]. Available from: https://bit.ly/344y18V

Mytelka LE, Farinelli F. Local clusters, innovation systems and sustained competitiveness. Maastricht: UNU-Intech; 2000. (Discussion paper).

Petter RR, Resende LM, Ceranto FAA, Martins R. Identificação do nível de maturidade do arranjo produtivo local de bonés de Apucarana. In: Encontro Nacional de Engenharia de Produção; 2010; São Carlos. São Carlos: Enegep; 2010. p. 1-14.

Rio Grande do Sul. Decreto n. 47.175, de 14 de abril de 2010. Assembleia Legislativa do Rio Grande do Sul, Porto Alegre (2010 Abr. 14): 1-4.

Santini S, Favarin EV, Nogueira MA, Oliveira ML, Ruppenthal JE. Fatores de mortalidade em micro e pequenas empresas: um estudo na região central do Rio Grande do Sul. Estratégia \& Negócios 2015; 8(1): 145-169. 10.19177/reen.v8e12015145-169

Saraceni AV, Andrade PP Jr. Proposta teórico-conceitual de desenvolvimento em arranjos produtivos locais. Revista Eletrônica Gestão e Sociedade 2013; 7(16): 92-111. 10.21171/ges.v7i16.1453

Serviço Brasileiro de Apoio às Micro e Pequenas Empresas SEBRAE. Anuário do trabalho na micro e pequena empresa: 2015. São Paulo: Dieese; 2015.

Silva CA, Cassol R. A utilização do geoprocessamento na quantificação econômica do extrativismo da erva-mate no município de Erechim. Perspectiva 2003; 27(97): 61-74.

Silveira MAP, Moraes TS. Mecanismos para identificação e estimulação de setores com potencial para formação de arranjos produtivos locais (APL). Reuna 2010; 15(3): 13-26.

Sindicato da Indústria do Mate no Estado do Rio Grande do Sul SINDIMATE. Dados estatísticos: erva-mate [Internet]. c2011 [cited 2016 Jun. 16]. Available from: https://bit.ly/2UrMg3v

Suzgan W, Furtado J, Garcia R, Sampaio SEK. Coeficientes de GINI locacionais - GL: aplicação à indústria de calçados do estado de São Paulo. Nova Economia 2009; 13(21): 39-60. 